\title{
Tingkat Pendidikan Ibu dan Penggunaan Oralit dan Zinc pada Penanganan Pertama Kasus Diare Anak Usia 1-5 Tahun: Sebuah Studi di Puskesmas Janti Malang
}

\author{
Ratna Kurnia Illahi $^{1^{*}, \text { Fitra Firnanda P }}{ }^{2}$, Bambang Sidharta ${ }^{1}$ \\ ${ }^{I}$ Bidang Farmasi Komunitas, Program Studi Farmasi Fakultas Kedokteran, Universitas Brawijaya Malang \\ ${ }^{2}$ Program Studi Farmasi, Fakultas Kedokteran, Universitas Brawijaya Malang
}

INFO ARTIKEL

Sejarah artikel:

Penerimaan naskah: 30

November 2015

Penerimaan naskah

revisi: 04 Desember

2016

Disetujui untuk

dipublikasikan: 20 Juni

2016

\section{Kata kunci :}

diare anak, tingkat pendidikan ibu, oralit,

zinc
A B S T R A K

Diare adalah suatu kondisi dimana seseorang buang air besar dengan konsistensi lembek atau cair, dan frekuensinya tiga kali atau lebih dalam satu hari. Diare merupakan salah satu masalah kesehatan anak yang utama di negara berkembang seperti Indonesia. Penanganan diare pada anak, terutama pemilihan terapi awal, dipengaruhi oleh beberapa hal diantaranya tingkat pendidikan ibu. Tujuan dari penelitian ini adalah untuk mengetahui pengaruh tingkat pendidikan ibu terhadap penggunaan oralit dan zinc dalam penanganan pertama diare pada anak usia 1-5 tahun. Oralit dan zinc adalah terapi awal yang disarankan pada kejadian diare anak, dengan tujuan untuk menggantikan garam elektrolit, air, dan zinc yang hilang saat terjadi diare. Penelitian dilakukan di Puskesmas Janti Malang sebagai salah satu Puskesmas yang banyak menangani kasus diare pada anak. Teknik pengambilan sampel dilakukan secara purposive sampling dengan responden sebanyak 100 orang. Pengambilan data penelitian dilakukan dengan pengisian kuesioner, yang sebelumnya telah diuji validitas dan reliabilitas, oleh responden. Hasil penelitian dianalisis dengan menggunakan chi-square dan diperoleh hasil signifikansi sebesar 0,528 (p > 0,05), dengan nilai koefisien korelasi yang diperoleh sangat rendah yaitu sebesar 0,176. Hasil tersebut menunjukkan bahwa tingkat pendidikan ibu tidak mempengaruhi penggunaan oralit dan zinc dalam penanganan pertama diare pada anak usia 1 hingga 5 tahun di Puskesmas Janti Malang.

\section{The Correlation of Mother's Education Level and the Usage of Oralit and Zinc in the First Treatment of Diarrhea on 1-5 Years Old Children: A Case Study in Puskesmas Janti Malang}

Keywords: children's diarrhea, mother's level of education, oralit, zinc

\begin{abstract}
A B S T R A C T
Diarrhea was a condition when a person experienced disturbing bowel movement and soft or liquid stool consistency, three times or more in a day. To this day, diarrhea is one of the major public health problems in developing countries including Indonesia. Mother's level of education, amongst other things, is likely influencing the treatment choice for children's diarrhea. The purpose of this study was to determined the influenced of mother's level of education on the use of oralit (oral rehydration therapy) and zinc in treating diarrhea experienced by children aged 1-5 years old. The study was done in Puskesmas Janti Malang, which was one of the primary health care frequently treating children with diarrhea. The sampling technique used was purposive sampling with 100 respondents. The instrument used was questionnaire that had been validated and reliability tested. The result of the study from chi square analysis gave the $\mathrm{p}$ value of 0.528 ( $p>0.05$ ), and coefficient correlation of 0.176 (very low). Thus, it can be concluded that the mother's level of education had no influence on the used of oralit and zinc for the first treatment of diarrhea amongst children aged 1-5 years old.
\end{abstract}




\section{Pendahuluan}

Diare adalah suatu kondisi dimana seseorang buang air besar dengan konsistensi lembek atau cair, dan frekuensinya tiga kali atau lebih dalam satu hari. Secara klinis penyebab diare dapat dikelompokkan dalam 6 golongan besar yaitu infeksi (disebabkan oleh bakteri, virus atau infeksi parasit), malabsorpsi, alergi, keracunan, imunodefisiensi dan sebab-sebab lainnya. Penyebab yang sering ditemukan di lapangan ataupun secara klinis adalah diare karena keracunan ${ }^{1}$.

Berdasarkan laporan UNICEF dan WHO tahun 2009, diare merupakan penyebab mortalitas dan morbiditas anak-anak dibawah lima tahun tertinggi kedua setelah pneumonia. Dilaporkan sebanyak 18\% (1,5 juta dari 9 juta) kematian pada anak di bawah lima tahun di dunia terjadi karena diare setiap tahunnya ${ }^{2}$.

Penyakit diare dibagi menjadi dua jenis yaitu diare akut dan diare persisten, yang memiliki cara penanganan dan pengobatan yang berbeda-beda. Penanganan dan pengobatan diare yang tidak tepat dapat menjadi masalah yang serius. Tingkat pengetahuan yang dimiliki ibu berpengaruh terhadap pemilihan obat-obatan dalam penanganan pertama diare pada anak, dan tingkat pengetahuan yg dimiliki ibu akan sangat dipengaruhi oleh tingkat pendidikan yang dimilikinya ${ }^{3}$.

Sejak tahun 2004, WHO dan UNICEF menandatangani kebijakan bersama dalam hal pengobatan diare yaitu pemberian oralit dan zinc selama 10-14 hari. Hal ini didasarkan pada penelitian selama 20 tahun (1980-2003) yang menunjukkan bahwa pengobatan diare dengan pemberian oralit disertai zinc lebih efektif dan terbukti menurunkan angka kematian akibat diare pada anak-anak sampai $40 \%{ }^{1}$. Pengetahuan yang cukup dimiliki oleh ibu akan mempengaruhi penanganan pertama diare pada anak dan diharapkan dapat mengurangi angka kematian yang terjadi karena diare.

Oleh karena itu, penelitian ini bertujuan untuk mengetahui pengaruh tingkat pendidikan ibu terhadap penggunaan penggunaan oralit dan zinc pada penanganan pertama diare pada anak usia 1-5 tahun, dan dilakukan di Puskesmas Janti Malang yang merupakan puskesmas yang banyak menangani kasus diare anak di Kota Malang. Diharapkan hasil penelitian dapat membantu menentukan strategi untuk memperluas pemberian informasi pada ibu mengenai penanganan pertama diare anak yang sesuai dengan anjuran WHO dan UNICEF.

\section{Metode}

\section{Desain penelitian.}

Penelitian ini merupakan penelitian deskriptif korelatif, dimana hasil yang diperoleh akan digunakan untuk menjelaskan hubungan antara variabel melalui pengujian hipotesis, dan dilaksanakan di Puskesmas Janti, Kecamatan Sukun, Kota Malang pada bulan Maret-Mei 2014. Instrumen yang digunakan adalah kuesioner yang terdiri dari 12 pernyataan mengenai penggunaan oralit dan zinc dalam penanganan pertama diare pada anak.

\section{Uji Validitas dan Reliabilitas.}

Sebelum digunakan sebagai instrumen penelitian, kuesioner harus diuji validitas dan reliabilitasnya pada populasi yang memenuhi kriteria sebagai sampel dengan jumlah 30 orang, yaitu di Puskemas Ciptomulyo Malang. Uji validitas dan reliabilitas dilakukan dengan menggunakan bantuan program SPSS IBM 20. Kuesioner dikatakan valid jika memiliki nilai probabilitas korelasi [signifikan (2tailed $)] \leq \alpha(0,05)$, dan suatu variabel dikatakan reliabel jika memberikan nilai alpha cronbach $>0,60$.

\section{Sampel}

Sampel penelitian ini adalah ibu-ibu yang sedang memeriksakan anaknya berusia 1-5 tahun karena diare dengan tingkat pendidikan apapun di Puskesmas Janti, Kecamatan Sukun, Kota Malang mulai bulan Maret sampai dengan Mei 2014 yang bersedia mengikuti penelitian dan memenuhi kriteria inklusi dan eksklusi. Jumlah sampel yang diambil adalah sebanyak 100 responden, yang didapat melalui perhitungan jumlah besar sampel menggunakan rumus dengan jumlah populasi tak terbatas (infinite) ${ }^{4}$.

\section{Kriteria Inklusi.}

Ibu dengan anak usia 1-5 tahun yang datang berkunjung ke Puskesmas Janti untuk memeriksakan anaknya yang sedang terkena diare dengan jenjang pendidikan apapun, dapat berkomunikasi dengan baik, bersedia menjadi responden.

\section{Kriteria Eksklusi}

Ibu yang datang ke Puskesmas Janti untuk memeriksakan anaknya yang sedang sakit selain diare, menolak untuk dilakukan wawancara, memberikan obat selain oralit dan zinc untuk mengatasi diare, ibu yang memiliki anak terkena diare usia 1-5 tahun yang sedang menjalani rawat inap di Puskesmas Janti.

\section{Analisis Data.}

Analisis yang digunakan pada penelitian ini adalah analisis kuantitatif. Tingkat ukuran yang dipakai dalam pengukuran variabel adalah dengan skala likert, dimana seorang responden dihadapkan pada beberapa pernyataan kemudian diminta memberikan jawabannya. Hasil perhitungan dari skor atau nilai kemudian digunakan dalam analisis statistik yang dilakukan dengan bantuan komputer menggunakan bantuan program SPSS IBM 20 untuk membuktikan hubungan dan pengaruh antar variabelvariabel penelitian. Setelah itu dilakukan pengujian dengan analisis chi-square. Dasar pengambilan keputusan penerimaan hipotesis berdasarkan tingkat signifikan (nilai a) sebesar 95\%, yaitu jika nilai $\mathrm{p}>\alpha(0,05)$ maka terdapat hubungan antara tingkat pendidikan ibu terhadap penggunaan oralit dan zinc pada diare anak, sedangkan jika nilai $\mathrm{p} \leq \alpha(0,05)$ maka tidak terdapat hubungan antara tingkat pendidikan ibu terhadap penggunaan oralit dan zinc pada diare anak. 


\section{Hasil}

\section{Karakteristik Responden}

Berdasarkan hasil penelitian diperoleh informasi mengenai karakteristik responden yaitu tingkat pendidikan terakhir ibu. Dari 100 responden yang menjadi sampel pendidikan terakhir ibu terbanyak yaitu tamat SMA atau sederajat yaitu sebanyak 52 responden dengan persentase $52 \%$. Sedangkan tingkat pendidikan terakhir ibu yang paling sedikit yaitu tidak tamat SD sebanyak 4 responden dengan persentase $4 \%$.

\section{Distribusi pernyataan kuesioner}

Berdasarkan hasil penelitian diperoleh informasi mengenai distribusi masing-masing pernyataan pada kuesioner. Kuesioner ini telah diuji validitas dan reliabilitasnya serta dinyatakan layak etik oleh Komite Etik Penelitian Kesehatan Fakultas Kedokteran Universitas Brawijaya dengan No. 176/EC/KEPK-S1-FARM/03/2014.

Pada Tabel 1 dapat dilihat bahwa pada pernyataan mengenai penggunaan oralit (pernyataan nomor 2, 3, 5, 6, 7, $10,11)$ sebagian besar responden dengan berbagai macam tingkat pendidikan menjawab setuju. Pada pernyataan mengenai penggunaan zinc (pernyataan nomor 4, 8, 9, 12), sebagian besar responden menjawab ragu-ragu. Skor penilaian penggunaan obat diare dapat dilakukan dengan penilaian sebagai berikut :

- Baik, apabila jawaban yang benar $>80 \%$ (total skor 36 dari 12 pernyataan).

- $\quad$ Sedang, apabila jawaban yang benar $60 \%-80 \%$ (total skor 36 dari 12 pernyataan).

- Kurang, apabila jawaban yang benar $<60 \%$ (total skor 36 dari 12 pernyataan).

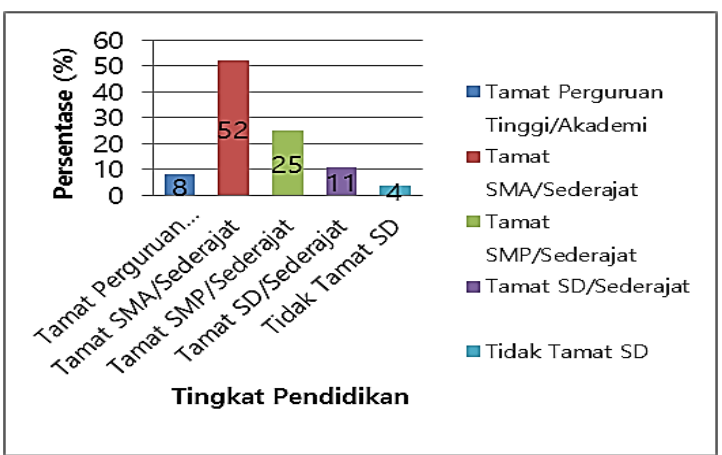

Gambar 1. Distribusi Frekuensi Tingkat Pendidikan Terakhir Ibu

Tabel 1. Distribusi Frekuensi Pernyataan Kuesioner Penggunaan Oralit dan Zinc dalam Pertolongan Pertama pada Diare Anak

\begin{tabular}{|c|c|c|c|}
\hline Nomor Pernyataan & $\begin{array}{c}\mathbf{S} \\
(\mathbf{n}, \%)\end{array}$ & $\begin{array}{c}\text { RR } \\
(\mathbf{n}, \%)\end{array}$ & $\begin{array}{c}\text { TS } \\
(\mathbf{n}, \%)\end{array}$ \\
\hline $\begin{array}{l}\text { 1. Diare merupakan buang air besar dalam } \\
\text { bentuk cair, lebih dari } 3 \text { kali dalam satu hari } \\
\text { dan biasanya berlangsung selama } 2 \text { hari atau } \\
\text { lebih }\end{array}$ & 96,96 & 0,0 & 4,4 \\
\hline $\begin{array}{l}\text { 2. Penanganan awal diare adalah dengan } \\
\text { mencegah terjadinya kekurangan cairan } \\
\text { (dehidrasi). }\end{array}$ & 95,95 & 3,3 & 2,2 \\
\hline $\begin{array}{l}\text { 3. Penanganan awal diare dirumah dapat } \\
\text { diberikan oralit. }\end{array}$ & 93,93 & 4,4 & 3,3 \\
\hline $\begin{array}{l}\text { 4. Anak dapat diberikan suplemen Zinc saat } \\
\text { diare. }\end{array}$ & 47,47 & 50,50 & 3,3 \\
\hline
\end{tabular}

5. Untuk mengatasi diare anak diberikan oralit sebanyak 1 sachet setiap kali habis $\mathrm{BAB}$ (Buang Air Besar).

6. Oralit dilarutkan dengan air matang sebanyak setengah gelas hingga satu gelas.

7. Oralit yang sudah dilarutkan kedalam air matang diberikan kepada anak sedikit demisedikit.

8. Suplemen zinc yang diberikan pada anak sebanyak 1 tablet tiap hari.

9. Suplemen Zinc dapat dikonsumsi dengan cara dikunyah atau dilarutkan dalam 1 sendok air matang.

10. Oralit diberikan pada anak setiap kali setelah BAB (Buang Air Besar).

11. Oralit diberikan sampai anak berhenti diare.

12. Suplemen Zinc dapat diberikan selama 10 hari berturut-turut walaupun diare sudah berhenti.

$\begin{array}{lll}84,84 & 13,13 & 3,3 \\ 97,97 & 3,3 & 0,0 \\ 83,83 & 10,10 & 7,7 \\ & & \\ 35,35 & 61,61 & 4,4 \\ 43,43 & 53,53 & 4,4 \\ 77,77 & 11,11 & 12,12 \\ 85,85 & 9,9 & 6,6 \\ 23,23 & 60,60 & 17,17\end{array}$

\section{Distribusi Frekuensi Penggunaan Oralit dan Zinc}

Berdasarkan penelitian yang telah dilakukan, diperoleh informasi mengenai distribusi frekuensi penggunaan oralit dan zinc secara keseluruhan, nama obat, cara penggunaan oralit dan zinc, dan waktu pemberian oralit dan zinc, yang disajikan pada Gambar 2.

Dilihat dari grafik mengenai penggunaan oralit dan zinc secara keseluruhan meliputi pengetahuan mengenai nama obat, cara penggunaan oralit dan zinc, dan waktu pemberian oralit dan zinc, sebagian besar responden dapat dikategorikan memiliki pengetahuan yang baik.

\section{Tabulasi Silang Antar Variabel}

Berdasarkan penelitian yang telah dilakukan diperoleh informasi mengenai tabulasi silang penggunaan oralit dan zinc secara keseluruhan, nama obat, cara penggunaan oralit dan zinc, dan waktu pemberian oralit dan zinc, yang disajikan pada Gambar 3.

Secara keseluruhan, tabulasi silang antara tingkat pendidikan terakhir ibu dengan penggunaan oralit dan zinc, tidak terdapat hubungan antara tingkat pendidikan terakhir ibu dengan penggunaan oralit dan zinc, terutama mengenai pengetahuan nama obat, cara penggunaan dan waktu pemberian.

\section{Uji Chi-Square}

Analisis yang digunakan pada penelitian ini adalah korelasi chi square dan koefisien kontingensi. Pengujian menggunakan bantuan program SPSS IBM 20 (Table 2).

Tabel 2 Hasil Uji Chi-Square

\begin{tabular}{ccccc}
\hline Kategori & $\begin{array}{c}\text { Tingkat } \\
\text { Pendidikan }- \\
\text { Penggunaan } \\
\text { Obat }\end{array}$ & $\begin{array}{c}\text { Tingkat } \\
\text { Pendidikan } \\
\text { Nama Obat }\end{array}$ & $\begin{array}{c}\text { Tingkat } \\
\text { Pendidikan }- \\
\text { Cara } \\
\text { Penggunaan } \\
\text { Obat }\end{array}$ & $\begin{array}{c}\text { Tingkat } \\
\text { Pendidikan }- \\
\text { Waktu } \\
\text { Pemberian } \\
\text { Obat }\end{array}$ \\
\hline $\begin{array}{c}\mathrm{X}_{\text {hitung }}^{2} \\
\text { Koefisien } \\
\text { Kontingensi }\end{array}$ & 3,179 & 12,639 & 11,241 & 15,452 \\
Sig. & 0,176 & 0,335 & 0,318 & 0,366 \\
$\mathrm{X}_{\text {tabel }}^{2}$ & 0,528 & 0,125 & 0,024 & 0,051 \\
(df; $\alpha=0,05)$ & 9,488 & 15,507 & 9,488 & 15,507 \\
Keterangan & $\begin{array}{c}\text { Tidak } \\
\text { Berhubungan } \\
\text { Signifikan }\end{array}$ & $\begin{array}{c}\text { Tidak } \\
\text { Berhubung- } \\
\text { an Signifikan }\end{array}$ & $\begin{array}{c}\text { Berhubungan } \\
\text { Signifikan }\end{array}$ & $\begin{array}{c}\text { Bidak } \\
\text { Berhubungan } \\
\text { Signifikan }\end{array}$ \\
\hline
\end{tabular}




\section{Diskusi}

Berdasarkan penelitian yang telah dilakukan, diperoleh data karakteristik responden berupa distribusi frekuensi tingkat pendidikan terakhir ibu yang disajikan pada gambar 1. Dari 100 responden, pendidikan terakhir ibu terbanyak yaitu tamat SMA atau sederajat yaitu sebanyak 52 responden dengan persentase $52 \%$, sedangkan tingkat pendidikan terakhir ibu yang paling sedikit yaitu tidak tamat SD sebanyak 4 responden dengan persentase $4 \%$. Berdasarkan frekuensi distribusi tingkat pendidikan terakhir tersebut maka sebagian besar responden memiliki tingkat pendidikan yang sedang.

Pendidikan mempengaruhi proses belajar, dimana semakin tinggi pendidikan seseorang makin mudah pula orang tersebut untuk menerima informasi baik dari orang lain maupun dari media massa. Semakin banyak informasi yang masuk, maka semakin banyak pula pengetahuan yang didapat tentang kesehatan. Seseorang dengan pendidikan formal yang lebih tinggi cenderung memiliki tingkat pengetahuan yang lebih tinggi bila dibandingkan dengan seseorang yang tingkat pendidikannya lebih rendah, namun seseorang yang berpendidikan rendah tidak berarti mutlak berpengetahuan rendah pula ${ }^{5}$.

Gambar 2. Distribusi Frekuensi Penggunaan Oralit dan Zinc secara Keseluruhan (A), nama obat (B), cara penggunaan oralit dan zinc (C), dan waktu pemberian oralit dan zinc (D).

Gambar 3. Tabulasi Silang Penggunaan Oralit dan Zinc secara Keseluruhan (a), Nama Obat (B), Cara Penggunaan Oralit dan Zinc (C), dan Waktu Pemberian Oralit dan Zinc (D).

Berdasarkan data hasil kuesioner yang diperoleh, didapatkan hasil berupa distribusi frekuensi tiap pernyataan yang disajikan pada tabel 1. Dapat dilihat pada tabel tersebut bahwa sebagian besar responden dengan tingkat pendidikan apapun menjawab setuju untuk butir pernyataan mengenai penggunaan oralit, sehingga dapat diketahui bahwa responden memiliki pengetahuan yang baik mengenai penggunaan oralit untuk penanganan pertama pada diare yang terjadi pada anak. Di sisi lain pada pernyataan mengenai penggunaan zinc, sebagian besar responden menjawab ragu-ragu, sehingga dapat diketahui bahwa sebagian besar responden dengan tingkat pendidikan apapun masih banyak yang belum mengetahui secara benar penggunaan zinc untuk mengatasi diare yang terjadi pada anak.

Pengunaan obat diare pada anak usia 1 hingga 5 tahun dalam penelitian ini meliputi pengetahuan mengenai pemilihan nama obat, cara penggunaan, dan lama waktu penggunaan. Obat diare yang dimaksud lebih ditekankan pada penggunaan oralit dan zinc sebagai penanganan pertama mengingat hal ini merupakan program yang diadakan oleh pemerintah dalam mengatasi diare sebelum anak dibawa ke sarana kesehatan terdekat. Menurut Departemen Kesehatan RI1, penanganan pertama yang dapat dilakukan pada kasus diare sebelum anak dibawa ke tempat pelayanan kesehatan yaitu segera diberikan oralit. Oralit diberikan untuk mengganti cairan dan elektrolit dalam tubuh yang terbuang saat diare. Meskipun air sangat penting untuk mencegah dehidrasi, air minum tidak mengandung
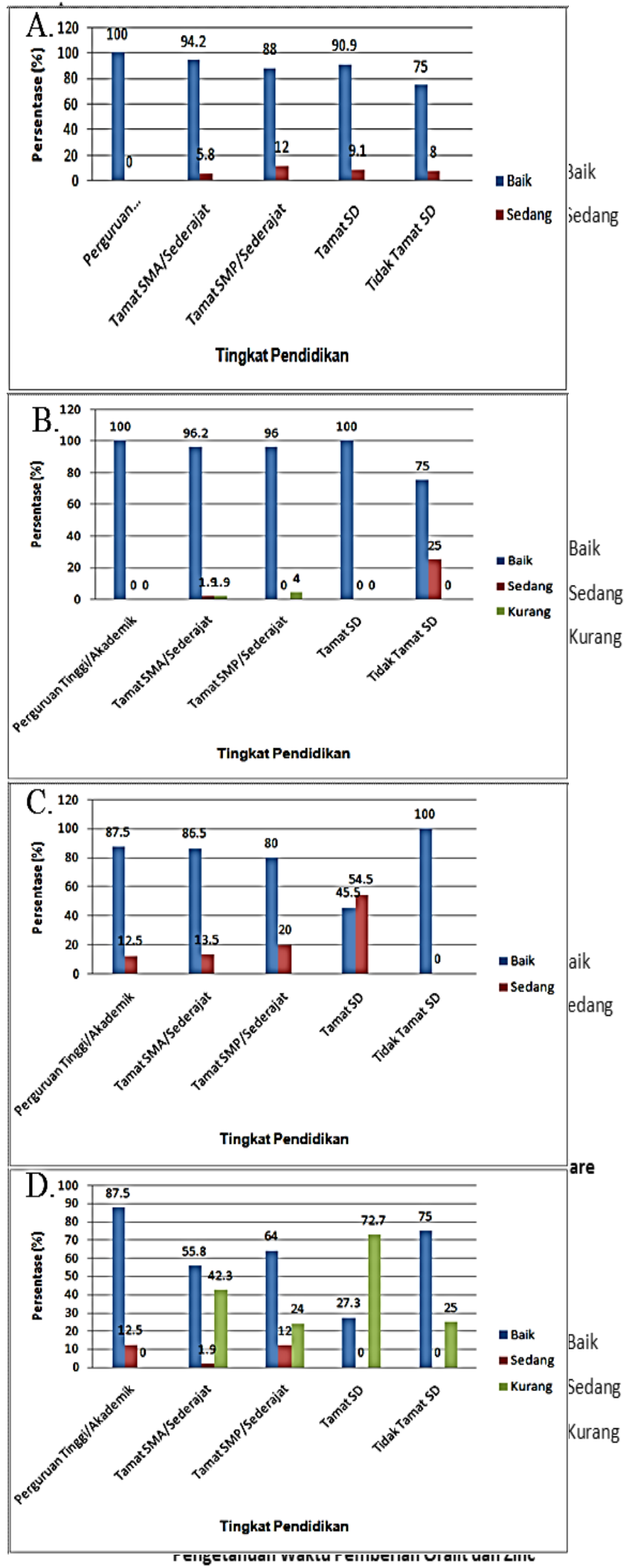

glukosa dan garam elektrolit seperti natrium klorida $(\mathrm{NaCl})$, kalium klorida $(\mathrm{KCl})$, dan trisodium sitrat hidrat yang diperlukan untuk mempertahankan keseimbangan elektrolit dalam tubuh, sehingga lebih diutamakan pemberian oralit. 
Campuran glukosa dan garam elektrolit yang terkandung dalam oralit dapat diserap dengan baik oleh usus penderita diare. Zinc merupakan salah satu zat gizi mikro yang penting untuk kesehatan dan pertumbuhan anak. Zinc yang ada dalam tubuh akan menurun dalam jumlah besar ketika anak mengalami diare. Untuk menggantikan zinc yang hilang selama diare, anak dapat diberikan zinc yang membantu penyembuhan diare serta menjaga agar anak tetap sehat. Sejak tahun 2004, WHO dan UNICEF menandatangani kebijakan bersama dalam hal pengobatan diare anak, yaitu dengan pemberian oralit dan zinc selama 10-14 hari. Hal ini didasarkan pada penelitian selama 20 tahun (1980-2003) yang menunjukkan bahwa pengobatan diare dengan pemberian oralit disertai zinc lebih efektif dan terbukti menurunkan angka kematian akibyang masuk, maka semakin banyak pula pengetahuan yang didapat tentang kesehatan. Seseorang dengan pendidikan formal yang lebih tinggi cenderung

at diare pada anak-anak sampai $40 \%$. Zinc diberikan satu kali sehari selama 10 hari berturut-turut, dan harus tetap dilanjutkan meskipun diare sudah berhenti. Hal ini dimaksudkan untuk meningkatkan ketahanan tubuh terhadap kemungkinan berulangnya diare pada $2-3$ bulan ke depan. Pada gambar 2, dapat dilihat pengetahuan mengenai frekuensi penggunaan oralit dan zinc pada diare anak, sebagian besar responden memiliki pengetahuan yang baik $(92 \%)$.

Pengolahan data tabulasi silang antara tingkat pendidikan terakhir ibu dengan penggunaan oralit dan zinc pada diare pada anak secara keseluruhan ditunjukkan pada gambar 3 (A), dengan hasil yang mengindikasikan bahwa tingkat pendidikan terakhir ibu tidak mempengaruhi penggunaan oralit dan zinc pada penanganan pertama diare pada anak. Salah satu contohnya, tabel tersebut menunjukkan bahwa sebanyak 8 responden $(100 \%)$ dengan tingkat pendidikan perguruan tinggi dan 10 orang responden dengan tingkat pendidikan terakhir tamat SD $(90,1 \%)$ memiliki pengetahuan yang baik mengenai penggunaan oralit dan zinc pada diare anak. Jika lebih dispesifikkan pada penggunaan obat yang terdiri dari pemilihan nama obat, cara penggunaan, dan waktu pemberian oralit dan zinc pada diare anak, diperoleh hasil yang ditunjukkan pada gambar 3 (BD). Pada poin pemilihan nama obat, terlihat bahwa ibu-ibu dengan tingkat pendidikan tamat SD memiliki pengetahuan yang kurang dibandingkan dengan tingkat pendidikan yang lebih tinggi. Namun secara umum, ibu-ibu dari berbagai tingkat pendidikan memiliki pengetahuan yang cukup baik mengenai penggunaan oralit dan zinc pada penanganan pertama diare anak.

Pendidikan adalah proses tumbuh kembang seluruh kemampuan dan perilaku menusia melalui pengajaran sehingga dalam pendidikan ini perlu dipertimbangkan umur (proses perkembangan) klien dan hubungannya dengan proses belajar. Pendidikan, baik secara langsung maupun tidak langsung mempengaruhi kualitas hidup, karena masyarakat dengan tingkat pendidikan tinggi akan mudah menerima informasi sehingga makin banyak pula pengetahuan yang dimiliki. Sedangkan seseorang dengan tingkat pendidikan yang rendah akan kesulitan untuk menyerap nilai-nilai yang baru diperkenalkan. Begitu pula dengan masyarakat yang memiliki tingkat pendidikan menengah, maka tingkat pemahamannya mengenai nilainilai baru juga berada pada taraf sedang ${ }^{6}$. Pengetahuan tentang kesehatan dalam keluarga termasuk di antara pengetahuan yang penting untuk diketahui agar tiap anggota dalam suatu keluarga lebih cepat menanggapi timbulnya masalah kesehatan, terutama pada kasus diare yang terjadi didalam suatu keluarga, maka diharapkan anggota keluarga dapat segera mengambil tindakan penanganan diare secepatnya ${ }^{6}$.

Setelah dilakukan tabulasi silang, kemudian dilakukan pengujian statistik yaitu menggunakan uji chisquare dengan bantuan program SPSS IBM 20. Hasil uji menggunakan chi-square dapat dilihat pada tabel 2 untuk mengetahui pengaruh tingkat pendidikan terakhir ibu terhadap penggunaan oralit dan zinc pada penanganan pertama diare anak usia 1 hingga 5 tahun. Secara keseluruhan diperoleh hasil signifikansi (p-value) sebesar 0,528 . Nilai ini lebih besar daripada nilai $\alpha(0,528>0,05)$ sehingga hipotesis penelitian Ha ditolak. Selain itu nilai koefisien korelasi yang diperoleh sangat rendah yaitu sebesar 0,176, sehingga hubungan yang terbentuk antara tingkat pendidikan ibu terhadap penggunaan oralit dan zinc pada diare pada anak usia 1 hingga 5 tahun adalah sangat rendah dan tidak signifikan, atau dapat dikatakan bahwa tingkat pendidikan ibu tidak mempengaruhi penggunaan oralit dan zinc dalam penanganan pertama diare pada anak usia 1 hingga 5 tahun.

Secara spesifik penggunaan obat pada penelitian ini meliputi pemilihan nama obat, cara penggunaan obat, dan waktu pemberian obat. Masing-masing telah dilakukan uji menggunakan chi-square yang terdapat pada tabel 2 . Hasil uji chi-square untuk mengetahui pengaruh tingkat pendidikan terhadap pemilihan nama obat diperoleh nilai signifikansi (p-value) sebesar 0,125 , dan nilai koefisien korelasi diperoleh rendah yaitu 0,335 . Pada hasil uji chisquare untuk menentukan pengaruh tingkat pendidikan ibu terhadap cara penggunaan oralit dan zinc pada tabel 2 diperoleh nilai signifikansi ( $p$-value) sebesar 0,024 , dan nilai koefisien korelasi sebesar 0,318 , sedangkan hasil uji chisquare untuk mengetahui pengaruh tingkat pendidikan terhadap waktu pemberian oralit dan zinc diperoleh nilai signifikansi (p-value) sebesar 0,051, dan nilai koefisien korelasi diperoleh rendah yaitu 0,366. Hasil tersebut menunjukkan bahwa tidak ada pengaruh signifikan antara tingkat pendidikan ibu dengan penggunaan oralit dan zinc pada penanganan pertama kasus diare anak usia 1-5 tahun di Puskesmas Janti Malang.

Hasil penelitian ini sejalan dengan hasil penelitian yang dilakukan oleh Endah ${ }^{7}$ mengenai tingkat pengetahuan, sikap, dan perilaku ibu dalam penanganan awal diare. Hasil penelitian tersebut menunjukkan tidak adanya hubungan antara tingkat pendidikan ibu terhadap pengetahuan mengenai penanganan awal diare. Menurut Sander ${ }^{8}$, jenjang pendidikan memegang peranan cukup penting dalam kesehatan masyarakat. Pendidikan masyarakat yang rendah 
menjadikan mereka sulit menerima informasi mengenai pentingnya bersikap higienis secara perorangan dan sanitasi lingkungan untuk mencegah terjangkitnya penyakit menular, diantaranya diare. Dengan sulitnya mereka menerima penyuluhan, menyebabkan mereka tidak peduli terhadap upaya pencegahan penyakit menular. Masyarakat yang memiliki tingkat pendidikan lebih tinggi lebih berorientasi pada tindakan preventif, lebih banyak mengetahu tentang masalah kesehatan dan memiliki status kesehatan yang lebih baik, contohnya jika tingkat pendidikan ibu lebih tinggi maka angka kematian bayi dan kematian ibu akan semakin rendah ${ }^{9}$. Perlu diperhatikan bahwa karakteristik setiap responden di setiap daerah berbeda beda, dan pengalaman memiliki pengaruh besar terhadap penangan awal pada diare anak. Ibu-ibu dengan tingkat pendidikan yang rendah jika telah berpengalaman terhadap penangan awal diare pada anak maka akan lebih memiliki pengetahuan mengenai penggunaan obat yang baik pada diare anak. Sebaliknya ibu-ibu dengan tingkat pendidikan tinggi namun belum berpengalaman terhadap penanganan awal diare pada anak, akan memiliki pengetahuan yang rendah pula mengenai penggunaan obat pada diare anak.

Hasil penelitian ini juga menunjukkan bahwa pemberian informasi mengenai penanganan awal diare anak menggunakan oralit dan zinc harus diberikan kepada semua ibu tanpa melihat tingkat pendidikan yang dimilikinya, karena tingkat pendidikan bukanlah satu-satunya faktor yang mempengaruhi pengetahuan ibu mengenai penangaan diare anak. Diharapkan pemberian informasi yang merata pada ibu-ibu akan membantu mengurangi resiko terjadinya kesalahan atau keterlambatan penanganan awal diare pada anak usia 1-5 tahun.

Kesimpulan dari penelitian ini adalah hasil uji menggunakan chi-square diperoleh hasil signifikansi ( $p$ value) sebesar 0,528 dan nilai koefisien korelasi yaitu sebesar 0,176, sehingga dapat disimpulkan bahwa tingkat pendidikan ibu tidak mempengari penggunaan oralit dan zinc dalam penanganan pertama pada diare anak usia 1 hingga 5 tahun. Sebagian besar responden dengan tingkat pendidikan apapun memiliki pengetahuan yang baik mengenai penggunaan oralit, sedangkan untuk penggunaan zinc, sebagian besar responden dengan tingkat pendidikan apapun masih banyak yang belum mengetahui penggunaannya secara benar.

\section{Daftar Pustaka}

1. Departemen Kesehatan Republik Indonesia. 2011. Buku Saku Petugas Kesehatan. Jakarta : Departemen Kesehatan Republik Indonesia.

2. Njeri, Grace and Moses Muriithi. 2013. Household Choice of Diarrhea Treatments for Children Under The Age of Five In Kenya: Evidence From The Kenya Demographic And Health Survey 2008-09. European Scientific Journal. Vol. 9 No. 6.
3. Ansari, Mukhtar, dkk. 2011. A Survey of Mothers' Knowledge About Childhood Diarrhoea and Its Management Among A Marginalised Community of Morang, Nepal. Australasian Medical Journal. Vol. 4 No. 9; 474-9.

4. Lwanga, S.K., dan Lemeshow, S.K. 1991. Sample Size Determination in Health Studies. Geneva : World Health Organization.

5. Widayatun, T.S. 2004. Ilmu Perilaku. Jakarta : CV Sagung Seto.

6. Notoatmodjo, Soekidjo., 2003. Pendidikan dan Perilaku Kesehatan. Jakarta : Rineka Cipta.

7. Endah Purbasari. 2009. Tingkat Pengetahuan, Sikap, dan Perilaku Ibu dalam Penanganan Awal Diare pada Balita di Puskesmas Kecamatan Ciputat, Tangerang Selatan, Banten Pada Bulan September Tahun 2009. (Skripsi) Fakultas Kedokteran dan Ilmu Kesehatan Masyarakat Universitas Islam Negeri Syarif Hidayatullah Jakarta.

8. Sander, M. A. 2005. Hubungan Faktor Sosio Budaya dengan Kejadian Diare di Desa Candinegoro Kecamatan Wonoayu Sidoarjo. Jurnal Medika. Vol 2. No.2. Juli-Desember 2005 : 163-193.

9. Widyastuti, P., (ed). 2005. Epidemiologi Suatu Pengantar, edisi 2. Jakarta : EGC. 